\title{
Metode Masase dan Interaksi Bayi pada Ibu Postpartum Terhadap Intensitas Nyeri
}

\section{Massage Methods and Infant Interaction in Postpartum Mothers on Pain Intensity}

\author{
Elita Vasra ${ }^{1, *}$, Suprida ${ }^{2}$ \\ 1,2Poltekkes Kemenkes Palembang, Jalan Inspektur Yazid, Sekip Jaya, Kemuning, Kota Palembang, Sumatera Selatan \\ 30114, Indonesia \\ 1'elita@poltekkespalembanga.ac.id*,2sup_rida@yahoo.com \\ * corresponding author \\ Tanggal Submisi: 10 November 2020, Tanggal Penerimaan: 20 januari 2021
}

\begin{abstract}
Abstrak
Nyeri dapat dirasakan mulai dari nyeri ringan-sedang sampai nyeri berat. tergantung dari banyaknya sumber penyebab nyeri. Tujuan untuk menemukan pengaruh terapi non invasif sesuai evidance based terhadap intensitas nyeri pada ibu postpartum di BPM Kota Palembang tahun 2017. Desain quasi experiment. Sampel 32 orang. Bertempat di PMB Limarini dan Husniyati Palembang. Hasil penelitian meunjukkan umur risiko tinggi 46,9\%, rendah 53,1\%. Paritas tinggi 59,4\%, rendah 40,6\%. Umur mempunyai hubungan $\mathrm{p}$ value 0,016 dan paritas tidak mempunyai hubungan $\mathrm{p}$ value 0,095 . Intesistas nyeri sebelum: sedang $71,9 \%$, berat $28,1 \%$. Intensitas nyeri sesudah: tidak nyeri $18,8 \%$, ringan $65,6 \%, 15,6 \%$. Rata-rata sesudah 1,97, SD 0,595 dan sebelum 3,28, SD 0,497. Dari hasil penelitian dapat disimpulkan ada hubungan umur dengan intensitas nyeri
\end{abstract}

Kata kunci : metode masase; interaksi bayi; post partum; intensitas nyeri

\begin{abstract}
Pain can be felt ranging from mild to moderate pain to severe pain. depending on the number of sources of pain. The aim was to find the effect of non-invasive therapy according to evidence based on pain intensity in postpartum mothers at BPM Kota Palembang in 2017. Quasi experimental design. Sample 32 people. Located at PMB Limarini and Husniyati Palembang. The results showed that the age of the high risk was $46.9 \%$, and the low risk was $53.1 \%$. Parity high $59.4 \%$, low $40.6 \%$. Age has a relationship with a p value of 0.016 and parity has no relationship with a $\mathrm{p}$ value of 0.095 . Pain intensity before: moderate $71.9 \%$, severe $28.1 \%$. After pain intensity: $18.8 \%$ painless, $65.6 \%$ mild, $15.6 \%$. The average after 1.97, SD 0.595 and before 3.28, SD 0.497. From the results of the study, it can be concluded that there is a relationship between age and pain intensity
\end{abstract}

Keywords: massage method; baby interaction; post partum; pain intensity

\section{PENDAHULUAN}

Nyeri merupakan kondisi berupa perasaan yang tidak menyenangkan. Sifatnya sangat subjektif karena perasaan nyeri berbeda pada setiap orang dalam hal skala atau tingkatannya, dan hanya orang tersebutlah yang dapat menjelaskan atau mengevaluasi rasa nyeri yang dialaminya. Bagian tubuh yang sering diderita keluhan nyeri adalah leher, tangan, kaki, dan daerah punggang. Seorang ibu haruslah menempatkan rasa sakit dalam sudut pandang yang benar, rasa sakit tidak akan terjadi selamanya. Pada ibu primigravida rasa sakit dapat berlangsung 12 sampai 14 jam, dari jumlah tersebut hanya beberapa jam saja yang benar- 
benar tidak nyaman. Nyeri persalinan merupakan rasa sakit yang terjadi akibat adanya aktivitas besar didalam tubuh guna mengeluarkan bayi. Di mana kontraksi dimulai dari bagian bawah punggung kemudian menyebar ke bagian bawah perut (Danuatmaja, 2013).

Associatione for the Study of Pain menyatakan nyeri merupakan pengalaman emosional dan sensori yang tidak menyenangkan yang muncul dari kerusakan jaringan secara aktual atau potensial atau menunjukkan adannya kerusakan. (Maryunani, 2010) Rasa sakit atau nyeri adalah informasi dari tubuh ke otak yang menyatakan atau meminta kita untuk lebih perhatian dan waspada karena ada sesuatu yang mengganggu. Ada tiga komponen dasar dalam rasa nyeri atau sakit yaitu komponen sensori atau komponen fisik yaitu bagaimana rasa nyeri atau sakit tersebut dirasakan secara nyata dari tubuh, komponen afektif atau emosi yang berhubungan tentang rasa/perasaan saat rasa nyeri dating, dan komponen kognitif/pemikiran, yang memikirkan jenis nyeri yang dirasakan. (Aprillia Yesie, 2014). Nyeri menyebabkan penderitaan dan stress. Katekolamin dilepas dari medulla adrenal dan menyebabkan penurunan pengosongan lambung, mual, muntah, dan peningkatan tekanan darah. Nyeri akut juga memicukorteks adrenal untuk melepaskan glukokortikoid. Akibat stress, nyeri akut meningkatkan ketegangan otot, tekanan darah, denyut nadi, dan frekuensi nafas. Nyeri yang tidak mereda dapat meningkatkan respons terhadap nyeri berikutnya. Emosi yang berkaitan dengan nyeri antara lain ketakutan, kemarahan, atau keputusasaan. (Murray, 2013).

Dampak-dampak negatif ini bila tidak diatasi akan mempengaruhi proses pemulihan ibu post partum. Nyeri pada ibu post partum terutama dirasakan pada hari pertama dan kedua, dimana fase adaptasi psikologis ibu masuk pada tahap taking in yaitu tahap dependent. Tahap ini ibu masih membutuhkan bantuan untuk memenuhi kebutuhan sehari-hari dengan porsi terbesar yang pemenuhan kebutuhan istirahat/tidur dan nutrisi. Bila nyeri yang terjadi pada fase ini tidak dapat diatasi maka akan memperpanjang fase taking in dan proses dependentindependent klien manjadi terhambat (Bobak, 2005). Tanpa melihat penyebabnya dan berapapun tingkatannya, nyeri termasuk salah satu masalah keperawatan yang harus diatasi oleh perawat/bidan. Tehnik untuk menurunkan nyeri secara non invasive saat ini telah banyak dikembangkan, namun belum ada laporan yang menjelaskan tehnik mana yang disarankan untuk digunakan pada nyeri post partum. Beberapa tehnik yang dapat digunakan antara lain tehnik pernafasan berirama, tehnik distraksi, dan tehnik stimulasi kutan. Masing-masing mempunyai kelebihan dan kelemahan. Telaah pemilihan tehnik untuk menurunkan nyeri sampai saat ini masih cenderung tergantung secara mutlak pada sebuah rencana standar umum yang berlaku, sehingga seringkali keunikan individu menjadi terlewatkan. Penggunaan metode evidence based practice lebih banyak memberi kesempatan kepada perawat untuk berpikir kritis dalam rangka mengambil keputusan dan melakukan tindakan yang tepat sesuai dengan masalah dan keunikan pasien. Evidence based practice yang diterapkan pada manajemen nyeri non invasive pada ibu post partum seperti masase wajah dan interkasi ibubayi, diharapan dapat membantu mempercepat proses pemulihan ibu pada fase puerperium dan mejadi distraksi nyeri yang ibu rasakan.

\section{METODE PENELITIAN}

Desain penelitian ini Quasi eksperimen dengan pre dan post test, Adapun quasi experiment yang akan digunakan yaitu non equivalent kontrol group design. Metode non equivalent kontrol group design adalah metode dimana seluruh grup dibagi menjadi dua grup yaitu grup terapi dan grup kontrol (Notoamodjo, 2002). Grup terapi yang menjadi sampel penelitian akan diobservasi terlebih dahulu sebelum diberi perlakuan, kemudian sampel tersebut akan diobservasi kembali setelah diberi perlakuan (Hidayat, 2009).

Bentuk rancangan dapat digambarkan sebagai berikut : 

$O_{1 a}$ $\mathrm{T}$
$\mathrm{O}_{2 a}$
(Kelompok terapi)

Dimana :

$O_{1}=$ Pengukuran pertama (pre test) dengan mengobservasi yang dilakukan kepada ke dua kelompok pasien inpartu

$\mathrm{O}_{2}=$ Pengkuran terakhir (post test) dengan mengobservasi yang dilakukan kepada kedua kelompok pasien inpartu

$\mathrm{T}=$ Perlakuan yang diberikan kepada kelompok ibu inpartu kala I

Penelitian berlokasi di BPM Lismarini dan Husniyati Palembang, Populasi adalah semua Ibu Postpartum yang masih dirawat di ruang rawat inap Bidan Praktik Mandiri Lismarini dan Husniyati Palembang

Sampel ditetapkan dengan

$$
\begin{array}{ll}
(\mathrm{r}-1)(\mathrm{t}-1) & \geq 15 \\
(\mathrm{r}-1)(2-1) & \geq 15 \\
(\mathrm{r}-1)(1) & \geq 15 \\
(\mathrm{r}-1) & \geq \frac{15}{1} \\
\mathrm{r}>15+1 & \stackrel{\mathrm{C}}{\longrightarrow} \mathrm{r} \geq 16
\end{array}
$$

Keterangan:

$\mathrm{r} \quad=$ sampel $/$ kelompok

$\mathrm{t} \quad=$ treatment (perlakuan)

Dari hasil data diatas pengambilan sampel kelompok berjumlah 16 orang untuk masingmasing perlakukan. Sehingga berjumlah 32 orang.

Teknik prngumpulan data adalah : Interview (wawancara) untuk menggali karakteristik ibu postpartum yaitu : umur dan paritas. Observasi (pengamatan) dapat berupa pemeriksaan inspeksi untuk melihat tingkatan atau intensitas nyeri sebelum dan sesudah dilakukan terapi non invasive. Pemeriksaan yang dilakukan adalah melakukan masase ringan pada wajah dan bahu. Instrumen pengambilan data adalah : Instrument pengukuran intensitas nyeri yang merupakan modifikasi VAS (Visual Analog Scale) dan NRS (nuemerical rating Scale) yang diterjemahkan dengan skala pengukuran borbounis (terlampir)

Hipotesis penelitian adalah : ada hubungan yang bermakna terapi non invasif pada ibu post partum terhadap tingkatan nyeri dan ada perbedaan sebelum dan sesudah ibu post partum yang diberikan terapi non invasif terhadap tingkatan nyeri

Etika Penelitian : Pada penelitian izin etichal clearance telah diterbitkan : oleh Komisi Etik Poltekkes Makasar dengan nomer sertifikat : 669/Kepk-PTKMKS/VII/2017

Pengolahan dan analisis data : Data yang telah terkumpul akan diolah dengan tahapan sebagai berikut : Editing \& Coding, Scoring, Entry data, Tabulasi data. Data di olah dengan sistim distribusi frekuensi dan dilakukan pengujian hubungan variabel dengan uji statistik. Rumus uji statistik yang di pakai adalah : Chi Square Test dan Uji $\mathrm{T}$ dengan derajat bermakna bila $\mathrm{p}$ value $<\alpha=0,05$.

\section{HASIL DAN PEMBAHASAN}

Penelitian ini telah dilakukan pada bulan Oktober s/d Awal Desember 2017, dengan desain quasi ekperimen pre-post test sampel yang didapatkan berjumlah 32 orang yang dilakukan intervensi yang sama 
Gambar 1. Distribusi Frekuensi Ibu Postpartum Berdasarkan Intensitas Nyeri Sebelum Intervensi

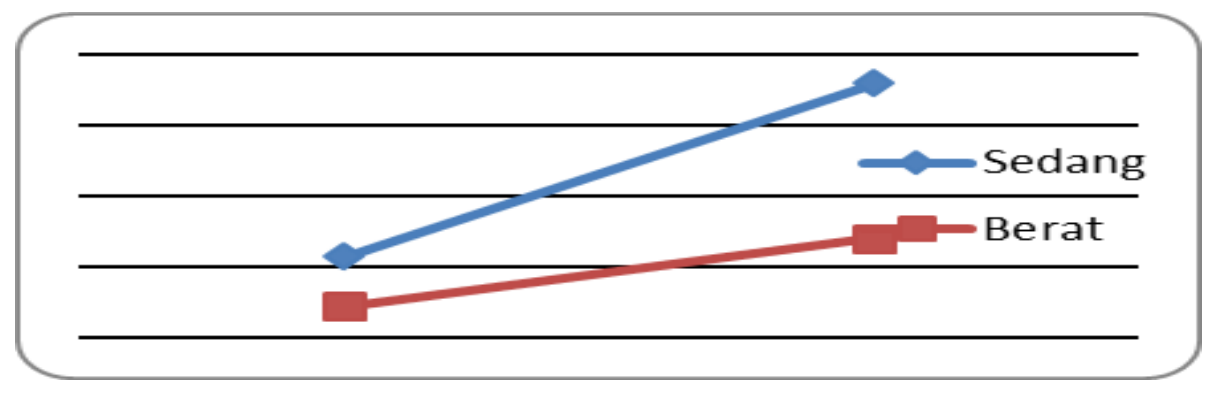

Pada tabel diatas dapat diketahui bahwa intesistas nyeri ibu sebelum dilakukan intervesi adalah : sedang berjumlah 71,9\% (23 orang) dan berat namun masih dapat dikontrol berjumlah $28,1 \%$ ( 9 orang).

Gambar 2. Distribusi Frekuensi Ibu Postpartum Berdasarkan Intensitas Nyeri Sesudah Intervensi

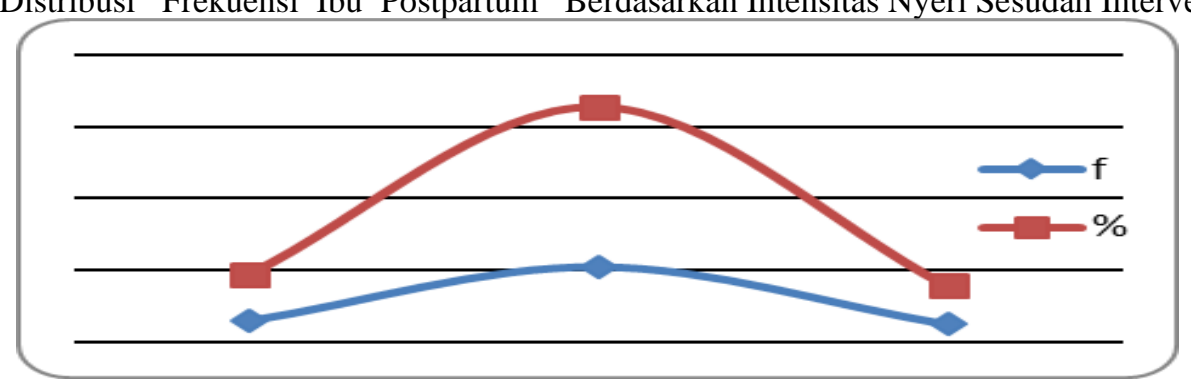

Pada tabel diatas dapat diketahui bahwa intensitas nyeri ibu postpartum sesudah dilakukan intervensi adalah : tidak nyeri berjumlah $18,8 \%$ (6 orang), ringan 65,6\% (21 orang) dan sedang berjumlah $15,6 \%$ (5 orang).

Tabel 1. Distribusi rata-rata Intensitas Nyeri pada ibu Postpartum dengan Terapi Non Invasif

\begin{tabular}{l|c|c|c|c|c}
\multicolumn{1}{c}{ Terapi Non Invasif } & Mean & SD & SE & P-Value & N \\
\hline Nyeri Sebelum & 3,28 & 0,457 & 0,081 & \multirow{2}{*}{0,000} & 32 \\
\hline Nyeri Sesudah & 1,97 & 0,595 & 0,105 & & 32
\end{tabular}

Rata-rata intensitas nyeri ibu post partum sesudah dilakukan terapi non invasif adalah 1,97 dengan SD 0,595 sedangkan intensitas nyeri sebelum dilakukan terapi non invasif adalah 3,28 dengan SD 0,497. Hasil uji statistik didapatkan $\mathrm{p}$ - value 0,000 pada alpha $5 \%$ terlihat ada perbedaan yang signifikan rata-rata.

a. Nyeri Pada Ibu Postpartum

Data Hasil penelitian ini menunjukkan bahwa intesistas nyeri ibu sebelum dilakukan intervesi adalah : sedang berjumlah 71,9\% (23 orang) dan berat namun masih dapat dikontrol berjumlah $28,1 \%$ ( 9 orang) dan intensitas nyeri ibu postpartum sesudah dilakukan intervensi adalah : tidak nyeri berjumlah 18,8\% (6 orang), ringan $65,6 \%$ (21 orang) dan sedang berjumlah 15,6\% (5 orang) data tersebut menunjukkan perubahan yang sangat signifikan dari pola nyeri sebelum intervensi dan setelah intervensi. Nyeri dapat dirasakan pada berbagai macam tingkatan mulai dari nyeri ringan-sedang sampai nyeri berat. Tingkatan nyeri yang dirasakan pasien post partum tergantung dari banyaknya sumber penyebab nyeri, toleransi pasien terhadap nyeri, dan faktor psikologis dan lingkungan (Carpenito, 2000; Potter dan Perry, 2006; Bobak, 2005; Rohmah. N. \& Walid, S. 2008). Nyeri berdampak sangat komplek bagi perawatan ibu post partum, antara lain: terhambatnya mobilisasi dini, terhambatnya laktasi, terhambatnya proses bondingattachment, perasaan lelah, kecemasan, kecewa karena ketidaknyamanan, gangguan pola tidur, dan bahkan bila nyeri berkepanjangan akan 
meningkatkan risiko post partum blues. Pada ibu post partum yang mengalami rasa nyeri bisa mendukung terjadinya stress yang akan meningkatkan keletihan (Mubarak, 2007:72)

Hasil persepsi ini akan di kembalikan ke dalam medulla spinalis melalui serat eferen dan reaksinya mempengaruhi aktifitas sel T. Rangsangan pada serat kecil akan menghambat aktifitas substansia gelatinosa dan membuka pintu mekanisme, sehingga merangsang aktifitas sel $T$ yang selanjutnya akan menghambat rangsangan nyeri (Uliyah, 2006). Prinsip pelaksanaan manajemen nyeri pada evidence based sesuai dengan konsep teori yaitu prinsip stimulasi kutaneus dan distraksi (Carpenito, 2000; Potter dan Perry, 2006; Adams, White, dan Beckett, 2010). Namun pada evidence based terdapat perbedaan pada area masase dan media distraksi. Area masase dipilih pada wajah dan bahu dengan pertimbangan adanya pemetaan nyeri yaitu area $1,2,3,4$, dan 5 . Area 1 dan 2 adalah area wajah yang merupakan area yang selalu mengalami ketegangan pada saat nyeri berlangsung, dengan melakukan masase pada daerah ini diharapkan dapat menjadi rileks sehingga dapat memutuskan mata rantai siklus takut-tegang-nyeri. Sedangkan area 3,4,5 adalah area yang dikeluhkan sebagai area nyeri. (Hamilton, 1998; Bobak, 2005; Strong, et all, 2002).

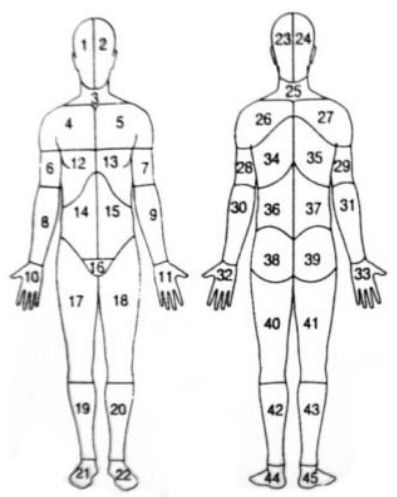

Gambar 3. Pemetaan area nyeri (Strong, et al., 2002)

b. Terapi Nyeri Non Invasif Terhadap Intensitas Nyeri Pada Ibu Postpartum

Data hasil penelitian ini menunjukkan intesistas nyeri ibu sebelum dilakukan intervesi adalah : sedang 71,9\% (23 orang) dan berat namun masih dapat dikontrol 28,1\% (9 orang) dan intensitas nyeri ibu postpartum sesudah dilakukan intervensi adalah : tidak nyeri 18,8\% (6 orang), ringan $65,6 \%$ (21 orang) dan sedang 15,6\% (5 orang), data tersebut menunjukkan perubahan yang sangat signifikan dari pola nyeri sebelum intervensi dan setelah intervensi. Dan jika dilihat dari perbedaaan rata-rata intensitas nyeri ibu post partum ssesudah dilakukan terapi non invasif adalah 1,97 dengan standar deviasi 0,595 sedangkan intensitas nyeri sebelum dilakukan terapi non invasif adalah 3,28 dengan standar deviasi 0,497. Hasil uji statistik didapatkan $\mathrm{p}$ - value 0,000 pada alpha $5 \%$ terlihat ada perbedaan yang signifikan rata-rata intensitas nyeri sebelum dan seudah terapi nyeri non invasif. Data tersebut juga menunjukkan selisih penurunan intensitas yang cukup besar yaitu 1,31

Dari hasil penelitian terkait yang duilakukan oleh Rochmah tahun 2011 adalah hasil data subyektif mengatakan "Nyeri skala 2". Sedangkan data obyektif menunjukkan wajah cukup rileks, gerakan masih hati-hati, TFU 2 jari bawah pusat, UC kuat, TD 110/80 mmHg nadi $80 \mathrm{x} /$ menit, RR $22 \times /$ menit, suhu $36,3^{\circ} \mathrm{C}$, BU (+) $12 \times /$ menit, tersenyum saat menerima kehadiran anaknya, menerima kehadiran bayi dengan senang saat dilakukan rawat gabung, kontak mata dengan bayi, menyentuh wajah bayi, tersenyum saat bayinya menetek, payudara lembek setelah disusukan, ASI kolo strum keluar, bayi dapat menghisap dengan efektif. Analisis nyeri akut teratasi. Planning RT dihentikan. Hasil penelitian sebelumnya berikut: Adams, White, dan Beckett (2010) menyimpulkan bahwa masase dapat menurunkan nyeri dari level rata-rata 5,18 (pada skala nyeri 0-1 VAS) menjadi 2,33 dengan nilai $\mathrm{p}<0,001$. 
Dalam penelitian ini menggunakan 65 sampel dan 26 diantaranya adalah dari unit obstetri. Walsh 2000 dalam Rochmat R. 2008 menyatakan bahwa walaupun tesedia obat-obat yang efektif, namun nyeri pasca bedah tidak dapat diatasi dengan baik, sekitar 50\% pasien tetap mengalami nyeri. Tindakan non invasiv sebaiknya terlebih dahulu dilakukan tanpa atau dengan tindakan farmakologis, karena hilangnya nyeri post partum dapat dipercepat jika menggunakan lebih dari satu tehnik (Hamilton, 1998 ; Bobak, 2005 ; Rochmat R. 2008).

Nyeri post partum adalah nyeri yang dirasakan seperti kram menstruasi saat uterus berkontraksi setelah melahirkan (Bobak, 2005). Selain itu nyeri post partum juga diartikan perasaan yang tidak menyenangkan yang merupakan mekanisme pertahanan diri dari berbagai penyebab dan dapat dimanifestasikan dalam respon fisik dan perilaku yang dirasakan ibu setelah melahirkan (Rohmah dan Walid, 2008). Intervensi nyeri post partum dapat dilakukan melalui kompres hangat, distraksi, imajinasi terbimbing, sentuhan terapiutik atau masase, interaksi dengan bayi (Hamilton, 1998: Carpenito, 2000; Bobak, 2005; Potter dan Perry, 2006; Rocmat, 2008). Masase bertujuan untuk menstimulasi produksi endhorpin dan dinorpin yang berfungsi untuk memblokade tranmisi nyeri melalui system control desenden. Sedangkan interaksi dengan bayi merupakan media distraksi yang bermaksud untuk mendominasi impuls yang masuk dalam system control asenden sehingga dapat menutup pintu gerbang penghantar nyeri. Dua intervensi ini diharapkan dapat secara sinergis menurunkan nyeri, karena hilangnya nyeri post partum dapat dipercepat jika menggunakan lebih dari satu tehnik (Hamilton 1998: Carpenito, 2000; Bobak 2005; Potter dan Perry, 2006; Rochmat, 2008; Adams, White, dan Beckett, 2010). Media distraksi yang digunakan adalah interaksi dengan bayi, media ini mempunyai banyak manfaat, selain untuk mengalihkan pusat perhatian dari nyeri media ini juga dapat dipakai untuk meningkatkan pembentukan bonding attachment. Interaksi dengan bayi merupakan media bonding. Bonding didefi nisikan sebagai suatu ketertarikan mutual pertama antar individu, misalnya antara orangtua dan anak, saat bonding

\section{SIMPULAN}

Umur mempunyai hubungan terhadap intensitas nyeri dan paritas tidak mempunyai hubungan terhadap intersintas nyeri, Intesistas nyeri ibu sebelum dilakukan intervesi adalah : sedang dan berat namun masih dapat dikontrol dan setelah intervensi intensitas menjadi tidak nyeri, ringan dan sedang Rata-rata intensitas nyeri ibu post partum sesesudah dilakukan terapi terlihat ada perbedaan yang signifikan rata-rata intensitas nyeri sebelum dan seudah terapi nyeri non invasif

Perlu dilakukan penelitian lebih lanjut tentang efek interaksi ibu-bayi terhadap penurunan nyeri post partum da Perlu dilakukan penelitian tentang nyeri akibat sensasi nyeri paska bedah dengan indikasi bedah umum berdasarkan pemetaan area nyeri

\section{REFERENCE}

Adams, White, and Beckett. (2010) The Effect Of Massage Therapy On Pain Management In The Acute Care Setting. International Journal Of Therapeutic Massage And Bodyworks. Volume 3, Number 1,P.4.11.March

Annisa, D, F \& Ifdil.(2016). Konsep Kecemasan (Anxiety) pada Lanjut Usia (Lansia).Jurnal Konselor. Volume 5 Nomor 2.Desember 10, 2019.http://ejournal. unp.ac.id/index.php/konselor/article/view/6480

Armini, N. W. (2016). Hypnobreastfeeding Awali Suksesnya Asi Eksklusif. Jurnal Skala Husada. Volume 13. No 1. November 10, 2019.http://ejournal.poltekkesdenpasar.ac.id/index.php/JSH/article

Aprilia Yesie. (2011). Gentle Birth Melahirkan Nyaman Tanpa Rasa Sakit, Jakarta: EGC. 
Bentelu, F. E. M., Kundre, R., \& Bataha, Y. B. (2015, Oktober).Perbedaan Tingkat Kecemasan Dalam Proses Menyusui Antara Ibu Primipara Dan Multipara Di Rs Pancaran Kasih Gmim Manado. Jurnal Keperawatan. Volume 3. No 2. November 25, 2019. https://ejournal.unsrat .ac.id/index.php/jkp/article/view/9593

Bidan Dosen Kebidanan Indonesia (2018). Kebidanan Teori dan Asuhan. Volume 1, EGC Bobak (2005). Buku Ajar Maternitas Edisi 4. Jakarta : EGC

Chapman Vicky. (2006). Asuhan Kebidanan Persalinan dan Kelahiran. Jakarta: EGC

Grasindo. (2014). Gentle Birth Balance, Bandung :Qanita Berman A. Buku Ajar Praktik Keperawatan Klinis. Jakarta: EGC

Gurnita, F. W., Suwondo, A., \& Astuti, R, S, E, P. (2020). Faktor Yang Mempengaruhi Tingkat Kecemasan Postpartum Primipara. JIKA, Volume 4, Nomor 2. April 5, 2020. http://e-journal.ar-rum.ac.id/index. php/ JIKA/article/view/94

Judha Mohamad, dkk. (2015). Teori Pengukuran Nyeri \& Nyeri Persalinan. Yogyakarta : Nuha Medica

Kementerian Kesehatan RI. (2019). Profil Kesehatan Indonesia tahun 2019. Pusdatin Kemenkes RI.

Komariah, N. (2017).Hubungan Antara Usia Ibu Dengan Tingkat Kecemasan Ibu Postpartum Di BPM Teti Herawati Palembang.Jurnal Kesehatan Palembang.Volume 12 No. 2.hlm: 103-107. April

5 ,

2020. https://jurnal.poltekkespalembang.ac.id/index.php/JPP/article/view/21

Laksana, H. (2017). Hypnotic Power Rahasia Membaca Dan Memengaruhi Isi Hati Dan Pikiran Orang Lain Dengan Hipnotis. Yogyakarta: Araska.

Marmi.,\& Magiyati. (2017). Pengantar Psikologi Kebidanan.Yogyakarta: Pustaka Pelajar.

Mardjun, Z., Korompis, G. \& Rompas, S. (2019). Hubungan Kecemasan Dengan Kelancaran Pengeluaran ASI Pada Ibu Postpartum Selama Dirawat Di Rumah Sakit Ibu Dan Anak Kasih Ibu Manado.Jurnal Keperawatan. Volume 7 Nomor 1. Hlm: 1-8. April 5, 2020.

Murray Michelle. (2013). Persalinan \& Melahirkan Praktik Berbasis Bukti. Jakarta : EGC Media Potter dan Perry (2006). Buku Ajar Fundamental Keperawatan Edisi 4. Jakarta : EGC Notoatmodjo, S. (2018). Metode Penelitian Kesehatan. Jakarta: Rineka Cipta.

Prawirohardjo, S. (2016).Ilmu Kebidanan. Jakarta: Bina Pustaka.

Prasetyo N.S. (2010). Konsep \& Proses Perawatan Nyeri. Yogyakarta : Graha Ilmu Rohani, dkk. (2011). Asuhan Kebidanan pada Masa Persalinan. Jakarta : Salemba Medika Rohmah, N. (2013). Manajemen Nyeri Non Invasive Pada Ibu Post Partum Dengan Pendekatan Evidence Based Practise. Digilib.unmuhjember.ac.id.

Roper, Nancy. (2000). Prinsip-prinsip Keperawatan. (Online), (www//http: emailbox@ cbn.net.id), diakses 20 Agustus 2017

Solehati, T., \& KosasiH, C.E. (2015).Konsep \& Aplikasi Relaksasi Dalam Keperawatan Maternitas. Bandung: PT Refika Aditama.

Sugiyono.(2016). Metode Penelitian Kuantitatif, Kualitatif, Dan R\&D. Bandung: ALFABETA.

Sastoasmoro, S dan Ismael S. (2011). Dasar-Dasar Metodologi Klinis. Jakarta : Sagung Seto

Sukma, F.(2017).Asuhan Kebidanan Pada masa Nifas.Jakarta: FKKUMJ.

Sutanto, A. V. (2018). Asuhan Kebidanan Nifas \& Menyusui. Yogyakarta: Pustaka baru press.

UNICEF.(2018). Enabling Women To Breastfeed Through Better Policies And Programmes.2019.November 30, 2019. https://www.who.int/global-bf-scorecard-2018 